\title{
Effect of habitat disturbance on distribution and abundance of Papyrus endemic birds in Sio Port Swamp, Western Kenya
}

\author{
STELLAH NEKESA WANYONYI, EVANS MUNGAI MWANGI", NATHAN GICHUKI \\ School of Biological Sciences, University of Nairobi. P.O Box 30197, Nairobi, Kenya, `email: emwangi@uonbi.ac.ke
}

Manuscript received: 17 May 2018. Revision accepted: 10 September 2018.

\begin{abstract}
Wanyonyi SN, Mwangi EM, Gichuki N. 2018. Effect of habitat disturbance on distribution and abundance of Papyrus endemic birds in Sio Port Swamp, Western Kenya. Bonorowo Wetlands 8: 51-62. Papyrus (Cyperus papyrus) swamps are found patchily around the shores of Lake Victoria, mainly along with river inflows. The objective of this study was to investigate the distinct forms of habitat disturbance and their implications on the distribution and abundance of papyrus endemic birds. Data on bird counts, habitat quality, and types of disturbance were collected for six months, from October 2013 to March 2014. Total bird counts were established using Timed Species Count (TSC) and playback call technique at every fixed point. The researcher waited for 1 minute, calls of the study species were played to elicit a response of the secretive papyrus endemic birds. The number of each bird's species seen or heard within a radius of 25 meters was recorded for the next 9 minutes before transferring to the next point count. Habitat quality such as height, density, and level of maturity was determined in a $1 \mathrm{~m}^{2}$ plot along transverse transects. Opportunistic observations were made to establish forms of disturbance present during vegetation and bird surveys. Papyrus endemic birds were highly distributed in sites with pure papyrus (55.58\%) than in places with mixed plants $(44.42 \%)$. The abundance of three endemic birds, White-winged Swampwarbler, Papyrus Gonolek, and Northern Brown-throated Weaver, was significantly different in mixed and pure papyrus sites. However, the abundance of Greater Swamp-warbler was not significantly different in mixed and pure papyrus sites in Sio Port Swamp during the study period. Forms of habitat disturbance established were vegetation clearing and invasion by terrestrial and aquatic plants. As many as $76.47 \%$ of papyrus vegetation were young and regenerated (0-2 $\mathrm{m}$ high), $19.65 \%$ were immature papyruses $(2-4 \mathrm{~m})$, whereas $3.88 \%$ were tall mature papyruses (4-6 m high). The abundance of papyrus endemic birds was positively and significantly correlated with the vegetation density in height ranging from 4-6 m. Thus, any change in papyrus density changed the abundance of papyrus endemic birds. Advance management of papyrus clearing is necessary for the long-term conservation of biodiversity.
\end{abstract}

Keywords: Sio Port Swamp, habitat disturbance, habitat quality, Papyrus endemic birds

\section{INTRODUCTION}

Wetlands are ecosystems that make up terrestrial and aquatic environments, namely, water, soil, and vegetation (Lathrop 2011). Wetlands occupy about six percent of the earth's surface area (Ramsar Convention Secretariat 2006). The exact extent of Kenya's wetlands is unknown due to the lack of a wetlands inventory. Nevertheless, it is estimated to be 3-4 percent of Kenya's landmass (Kenya Wetlands Atlas 2012) that can temporarily rise to 6 percent in the rainy season (Mwakubo and Ikiara 2006; Kenya Wetlands Forum 2012).

Papyrus swamps dominated by Cyperus papyrus form a distinctive wetland type in tropical Africa, supporting many endemic species (Hughes and Hughes 1992). In Kenya, papyrus swamps are patchy and are found primarily along river inflows and at the mouth of main rivers and lakes (Britton 1978; Bennun and Njoroge 1999; Boar et al. 1999). Papyrus swamp occurs as intact patches of continuous fringe along the shores of Lake Victoria.

Papyrus swamps have essential ecological, hydrological, and economic functions (Mafabi 2000). The ecosystems provide water and primary productivity upon which many animal species rely for survival. Around Lake Victoria are of great significance for wildlife conservation as they host papyrus specialist birds, including the Papyrus Yellow Warbler Chloropeta glacilirostris, Papyrus Gonolek Laniarius mufumbiri, White-winged Swamp Warbler Bradypterus carpalis, Papyrus Canary Serinus koliensis, and Carruthers's Cisticola Cisticola carruthersi (Van de Weghe 1981; Nasirwa and Njoroge 1997; Bennun and Njoroge 1999; Mafabi 2000; Byaruhanga et al. 2001; BirdLife International 2004). Papyrus Yellow Warbler and Papyrus Gonolek are listed as globally threatened and require urgent conservation action (BirdLife International 2004).

Increased human population, especially in sub-Saharan Africa, has led to a decline in wetland goods (Balirwa 1998). Poverty amongst riparian communities has led to unsustainable encroachment on wetland ecosystems leading to continuous drainage, pollution, overexploitation, and unsustainable use of wetland resources. Africa's total region covered by papyrus swamps is approximately 4,000 $\mathrm{km}^{2}$ (Percy FitzPatrick Institute of African Ornithology 2005). The extent of most wetlands is probably decreasing because of human encroachment and intensified land-use changes around them (Hughes and Hughes 1992; Mafabi 2000; Kairu 2001). 


\section{MATERIALS AND METHODS}

\section{Study area}

Sio Port Swamp is located in the Lake Victoria North Drainage basin on the Kenya-Uganda border (Figure 1), at latitude $0.2242^{\circ} \mathrm{N}$ and longitude $34.0217^{\circ} \mathrm{E}$, at an altitude of 1,130 m above sea level (Bennun and Njoroge 1999). It is located in Busia County in the western part of Kenya. Sio Port Swamp is an inland wetland, a permanent herbaceous swamp, and bog. It consists of other interconnected subsystems that drain Lake Victoria (Kenya Wetland Atlas 2012). This swamp is dominated by papyrus Cyperus papyrus vegetation. The swamp has an area of 400 hectares, and it is fed by River Sio, which originates from the southern slopes of Mt. Elgon (Barasa et al., 2011). The river is permanent and has a total length of $85 \mathrm{~km}$ and a catchment area of $1,388 \mathrm{~km}^{2}$ (GoK 2009).

This study was carried out between October 2013 to March 2014 (six consecutive months). The study period comprised two seasons; wet (October to December) and dry (January to March). Five bird species endemic to the papyrus habitat were studied, i.e., White-winged Swampwarbler Bradypterus carpalis, Papyrus Gonolek Laniarius mufumbiri, Greater Swamp-warbler Bradypterus rufescens, and Northern Brown-throated Weaver Ploceus castanops.

\section{General methods}

Stratification of the study site

Sio Port Swamp had vegetation ranging from tall grass to papyrus at different stages of regeneration. The most dominant plant was papyrus. Some regions had pure papyrus vegetation that was almost undisturbed, while some areas had a mixture of grass and papyrus vegetation. The variations in papyrus distribution were used as the basis for the stratification of the swamp.

Transverse transects were selected from the pathways fishers and other local people used to access the lake from the land. Five transects were identified based on the ability to penetrate the papyrus habitat without necessarily creating additional paths, which would otherwise have been tedious, expensive, and destructive. Transects had local names as Ongaro, Sio, Daniel, Busijo a, and Busijo b (Figure 1. A).

Sio, Busijo a, and Busijo b had a mixture of papyrus vegetation and grass, and they were identified as mixed papyrus (MP) (Figure 2. A). Ongaro and Daniel had almost undisturbed papyrus vegetation; they were classified as pure papyrus (PP) (Figure 2. B)

Transects were of varying lengths and had a different number of sampling points (Table 1).

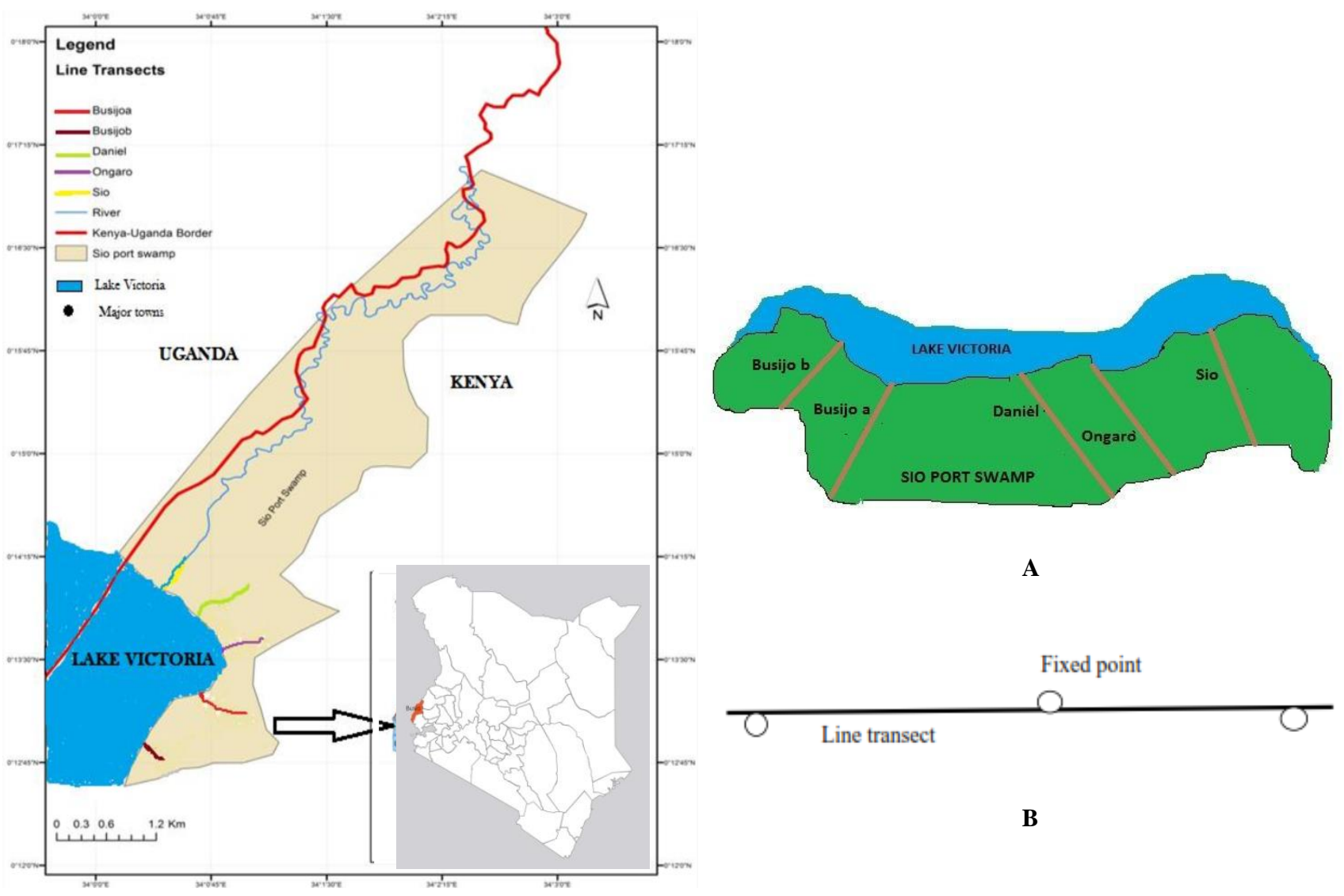

Figure 1. Study area showing features and line transects at Sio Port Swamp, Busia County, Western Kenya. A. Sketch map for the study site in Sio Port Swamp, Western Kenya, showing the transverse transects. B. Fixed points set up along a line transect 


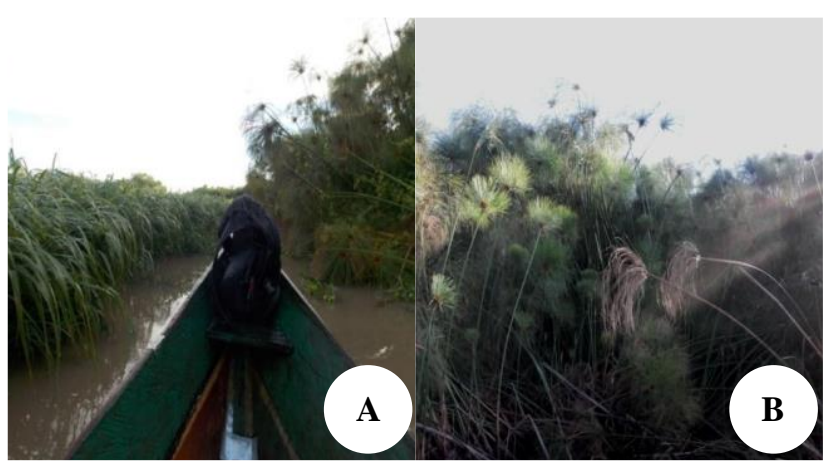

Figure 2. Sections of mixed papyrus (A) and pure papyrus stratum (B) in Sio Port Swamp, Western Kenya (Photo by SNW, Jan 2014)

Table 1. Transect name, length, and the number of points present in the Sio Port Swamp, Western Kenya

\begin{tabular}{llcc}
\hline Stratum & $\begin{array}{c}\text { Transect } \\
\text { name }\end{array}$ & $\begin{array}{c}\text { Transect } \\
\text { length (m) }\end{array}$ & $\begin{array}{c}\text { Number of } \\
\text { points per } \\
\text { transect }\end{array}$ \\
\hline Mixed papyrus (MP) & Sio & 300 & 7 \\
Mixed papyrus (MP) & Busijo a & 200 & 5 \\
Mixed papyrus (MP) & Busijo b & 50 & 2 \\
Pure papyrus (PP) & Ongaro & 200 & 5 \\
Pure papyrus (PP) & Daniel & 500 & 11 \\
\hline
\end{tabular}

\section{Establishment of observation points}

Observation or fixed points were identified systematically according to the nature of the habitat and marked using a GPS along the transverse line transects, at least $50 \mathrm{~m}$ apart. The observation points were set up alternating left and right along the transects (Figure 1. B).

\section{Specific methods}

Estimation of the population size of endemic birds

The birds were observed between 0700 hrs and 0900 hrs every morning of each day of the study period. Most fishers would have returned to the beach after their catch during this time. Hence there was minimal disturbance while conducting the counts.

Timed species count technique and playback calls were used to detect and estimate the number of individual bird species using the habitat. The timed species count (TSC) method involves repeated species lists. Each species is recorded the first time positively identified by either sight or sound (Bennun and Howell 2000; Sutherland 1996). The playback call technique involves playing recorded sounds of the target bird species. It is mainly used to elicit a response from secretive birds, which on hearing the calls, will call back or move in search of the 'other' bird.

At every fixed-point count, the researcher waited for 1 minute, calls of the study species were played to elicit a response of the secretive papyrus endemic birds. The number of each species of birds seen or heard within a radius of 25 meters was recorded for the next 9 minutes prior at every point count. Birds seen or heard beyond the set distance were not included. Observations were carried out in all directions, with observers standing back to back to reduce chances of double countings, such as when a bird flew from one side to the other. A pair of binoculars was used to observe cases where a bird could not be easily recognized due to interception by vegetation. The inspection was done at all the fixed points along all transects.

\section{Identification of forms of disturbance}

Opportunistic observations were made along transects to establish any disturbance present. The types of disturbance were placed into two main categories: vegetation clearing and invasion by terrestrial or invasive plants. Vegetation clearing involves vegetation cutting, cultivation, vegetation burning, and livestock grazing. The frequency of occurrence of each type of disturbance was recorded during the vegetation and bird surveys along all transects.

\section{Determination of quality of habitat}

Vegetation height and density were used to describe the habitat quality in Sio Port Swamp. The previous report indicated that local papyrus habitat-specific characteristics, i.e., height and percentage cover, provided the best means of predicting the existence of papyrus specialist birds because the birds are sensitive to papyrus physical structure (Owino and Ryan 2006). The height of papyrus culm was also described regarding the stages of maturity: young, immature, and mature (Sutton and Hudson 1981).

At every fixed point, a plot of $1 \mathrm{~m}$ by $1 \mathrm{~m}$ was set up using the pieces of marked wood. The number of papyrus culms in each plot was counted and recorded to give density. A long pole and part of the stick marked at different length intervals (in meters) were used to estimate the height of papyrus vegetation. The height of each stem or culm sampled was recorded in either of the three height ranges; 0-2 m, 2-4 m, and 4-6 m coinciding with the variety of young papyrus, immature papyrus, and mature papyrus, respectively.

\section{Data analysis}

Data on bird counts, vegetation density, and vegetation height were subjected to statistical analysis where the size, mean, and standard deviation were calculated. The normality was analyzed using the Shapiro-Wilk test of the p-value followed by log transformation of skewed data where necessary (Zar 2010). Data analysis was done using IBM SPSS Statistical software version 20.

The number of birds counted at each vegetation stratum was assumed to be independent. The density of individual bird species was determined by dividing the number of birds of each species by the total area sampled ( $5.89 \mathrm{ha}$ ).

The population size of individual bird species was estimated using the incomplete count method, which does not involve the number of birds occurring beyond the estimated radius (25 meters). The nature of papyrus vegetation in the habitat could not allow observations to be made beyond 25 meters. This population size (Burnham et al. 1980) methods were used where;

$\mathrm{N}=$ estimated bird population size 
$A=$ total area of the study site (ha)

$\mathrm{Z}=$ number of individuals of a species counted 24

$\mathrm{X}=$ total distance covered

$\mathrm{Y}=$ double width of radius

Analysis of Variance compared the distribution of papyrus endemic birds in points along transects determined the difference in the plenty of the endemic birds in pure and combined papyrus stratum. Furthermore, it compared vegetation density of different height ranges in mixed and pure papyrus strata.

Bar graphs were constructed using the density of endemic birds calculated in all sites to reveal the average distribution of the birds in points along transects.

Culm height and culm density determined the birds' habitat quality. These are essential characteristics for papyrus specialist birds, as they provide suitable habitat conditions for nesting and feeding (Owino and Ryan 2006). Data on vegetation height was organized into various classes (0-2 m, 2-4 m, and 4-6 m). The average height for each class was then determined in all transects for all the vegetation sampled. Correlation analysis examined the relationship between vegetation density and vegetation height. In contrast, regression analysis (performed only for significant correlation) was used to determine the relationship between the numbers of birds of each species with vegetation density.

\section{RESULTS AND DISCUSSION}

\section{Species and abundance of Papyrus endemic bird}

A total of four papyrus endemic birds, namely, Papyrus Gonolek, White-winged Swamp-warbler, Greater Swampwarbler, and Northern Brown-throated Weaver, were observed in Sio Port Swamp and studied during the period between October 2013 and March 2014.

Four species comprised of 501 individuals (Whitewinged Swamp-warbler; Papyrus Gonolek; Northern Brown-throated Weaver and Greater Swamp-warbler) were recorded during the study. Out of this number, 222 were Northern Brown-throated Weaver, 114 were White-winged Swamp-warbler, 101 were Papyrus Gonolek, and 64 were Greater Swamp-warbler. Table 2 summarized the estimated density, population size, and proportion of the four endemic bird species studied in Sio Port Swamp (400 ha).

Table 2. Estimated densities and population size of papyrus endemic birds studied in Sio Port Swamp, Western Kenya (October 2013-March 2014)

\begin{tabular}{|c|c|c|c|}
\hline Bird name & $\begin{array}{c}\text { Density } \\
\text { (birds/ha) }\end{array}$ & $\begin{array}{c}\text { Estimated } \\
\text { population } \\
\text { size }\end{array}$ & $\begin{array}{c}\text { Proportion } \\
(\%)\end{array}$ \\
\hline $\begin{array}{l}\text { White-winged Swamp- } \\
\text { warbler }\end{array}$ & 19.36 & 7,296 & 23 \\
\hline Papyrus Gonolek & 17.16 & 6,464 & 20 \\
\hline $\begin{array}{l}\text { Northern Brown-throated } \\
\text { Weaver }\end{array}$ & 37.71 & 14,208 & 44 \\
\hline Greater Swamp-warbler & 10.87 & 4,096 & 13 \\
\hline
\end{tabular}

Table 3. Forms of disturbance in points along transects in the Sio Port Swamp, Western Kenya (October 2013 to March 2014)

\begin{tabular}{lll}
\hline Transect name & Form of disturbance & Points where recorded \\
\hline Sio & Vegetation clearing & II, IV, V, and VI \\
& Invasion & All points \\
Busijo a & Vegetation clearing & III \\
& Invasion & All points \\
Busijo b & Vegetation clearing & I and II \\
& Invasion & II \\
Ongaro & Vegetation clearing & II, III, IX, and X \\
& Invasion & None of the points \\
Daniel & Vegetation clearing & II, III, IV, and V \\
& Invasion & III, IV, and V \\
\hline
\end{tabular}

\section{Habitat disturbance in Sio Port Swamp}

Forms of disturbance in Sio Port Swamp

The types of vegetation disturbance recognized during the study were vegetation clearing and invasion by terrestrial and aquatic plants. Vegetation clearing was the most trivial form of distress compared to invasion by terrestrial and aquatic plants (Table 3).

\section{Vegetation clearing}

Vegetation clearing was mainly done by burning vegetation, livestock grazing, cutting of papyrus culms, and cultivation on the edges of the swamp. Vegetation burning was one of the most frequent forms of vegetation clearing found throughout the study period, and it occurred in patches in parts of the swamp (Figure 3). Papyrus was the primary vegetation affected. Vegetation burning was frequent in the dry season compared to the wet season.

Besides vegetation burning, vegetation cutting was also a common vegetation disturbance in Sio Port Swamp from October 2013 to March 2014. Several patches of cut papyrus were observed in different swamp parts (Figure 4). Mature and old papyruses were the main stages of growth that were cut.

Vegetation cutting was mainly done to obtain culms for making baskets, mats, and for thatching houses. Besides this, vegetation clearing was done to create fish traps within the swamp. Clearing of vegetation to set up fish traps was frequent in the transect named Daniel. Besides fishing deep in the lake, trap fishing was universal, especially by locals who exploited fish mainly for domestic use. The fish traps located across transects were primarily made of papyrus culms (Figure 5. A). Bundles of dry papyrus culms were seen piled next to the fish traps (Figure 5. B).

Vegetation was cleared along the edges of the swamp to create room for cultivation. The main crops planted were sugarcane, kales (Figure 6), and maize. The vegetables were the source of food and income for the local community.

Vegetation clearing through livestock grazing was frequent in the transect named Ongaro and Busijo b. Fifty cows and seventy-three sheep could be seen grazing along the edges of the swamp, where the ground was firm and dry from October 2013 to February 2014. These animals appeared to forage closer to the side of the swamp during 
the dry season than during the wet season. Livestock grazing resulted in trampling and vegetation removal along the edges of the swamp, thereby slowing down regeneration. A large concentration of grazing animals harms plants due to selectivity and overgrazing (Kamau 2004).

\section{Invasion by terrestrial and aquatic plants}

Invasion by woody terrestrial plants was common in transects located in the mixed papyrus stratum. Hippo grass (Vossia cuspidata) (Figure 7. A) was the most common invasive grass growing to heights of about 3-4 m. The other widespread invasive plant was the water hyacinth (Eichhornia crassipes) (Figure 7. B). Other invasive plants observed in Sio Port Swamp from October 2013 to March 2014 included; morning glory (Ipomoea stolonifera), bulrush (family Cyperaceae), and wandering jew (Commelina spp.).

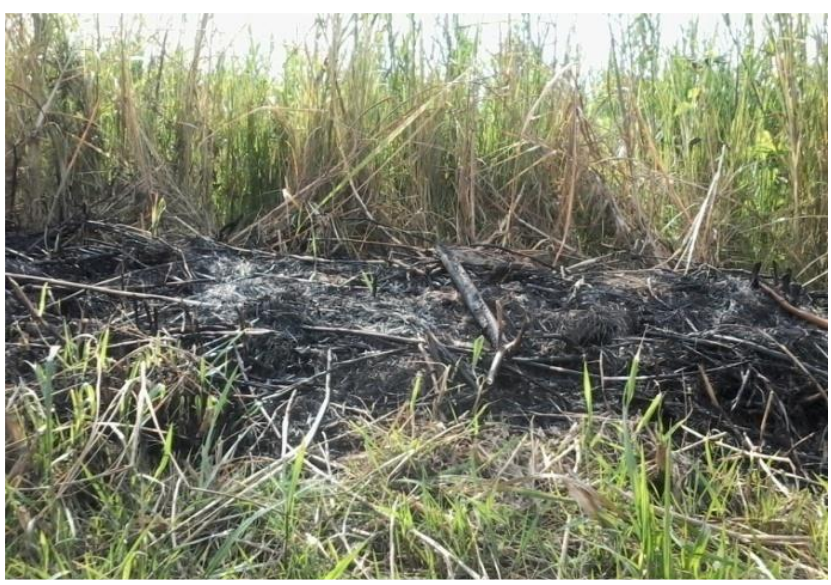

Figure 3. Burnt vegetation in a part of Sio Port Swamp, Western Kenya (Photo by SNW, Feb 2014)

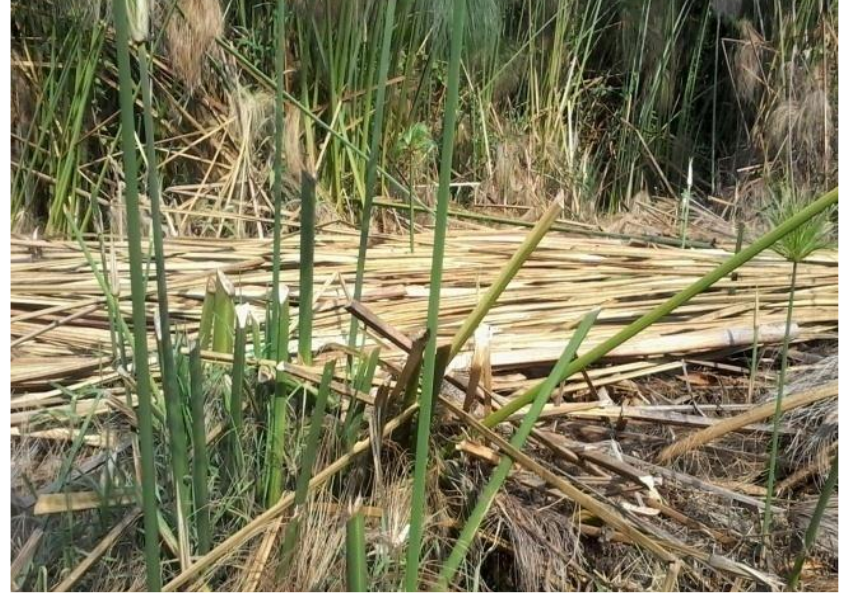

Figure 4. Harvested papyrus in a part of Sio Port Swamp, Western Kenya (Photo by SNW, Feb 2014)
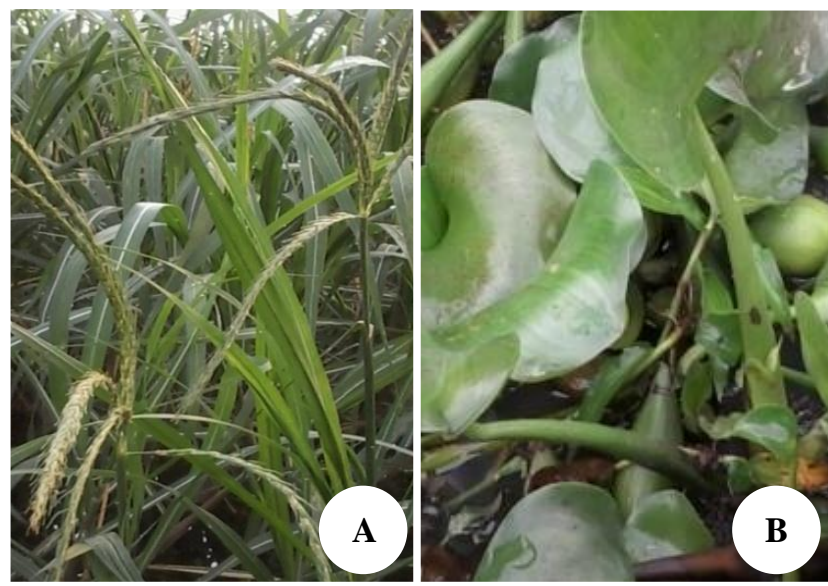

Figure 7. Invasive aquatic grass Vossia cuspidata at a distributary of River Sio, Western Kenya (A) and Invasive aquatic plant; water hyacinth Eichhornia crassipes (B) (Photo by SNW, Nov 2013 and Jan 2014)
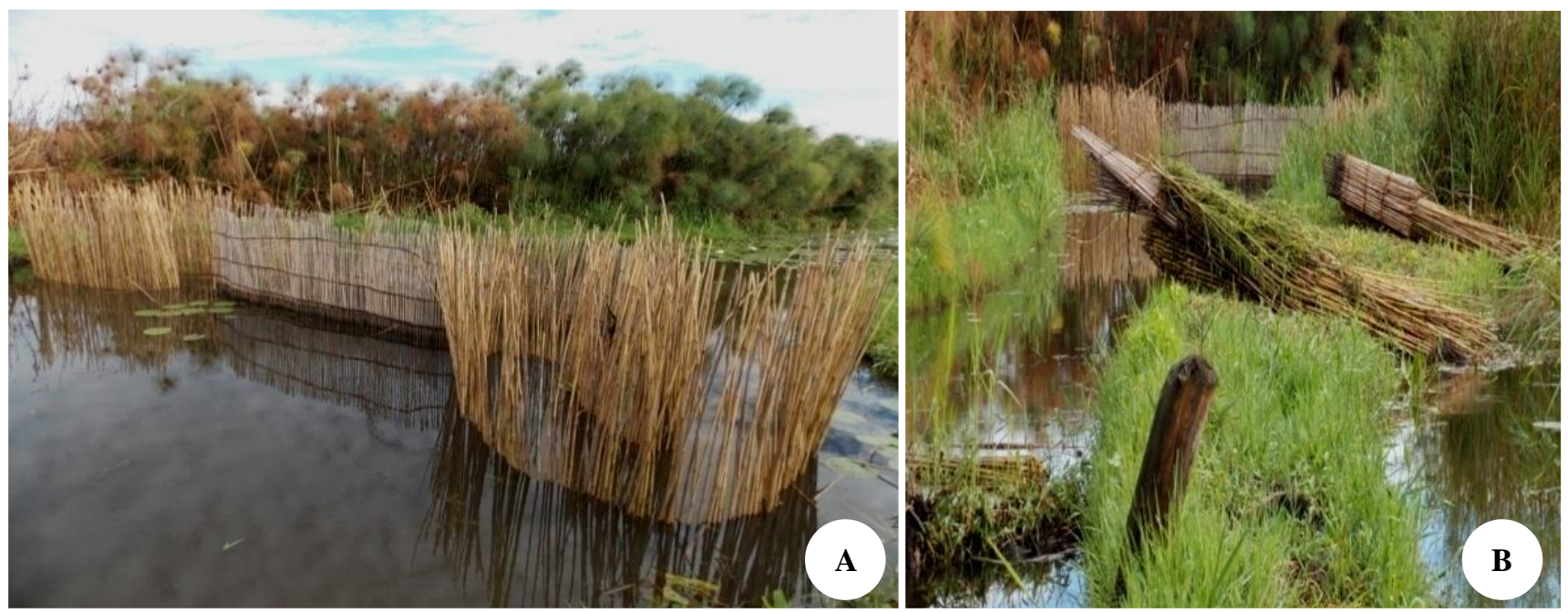

Figure 5. Fish trap set up in Daniel transect (A), piles of papyrus culms next to a fish trap of Sio Port Swamp, Western Kenya (B) (Photo by SNW, Dec 2013) 

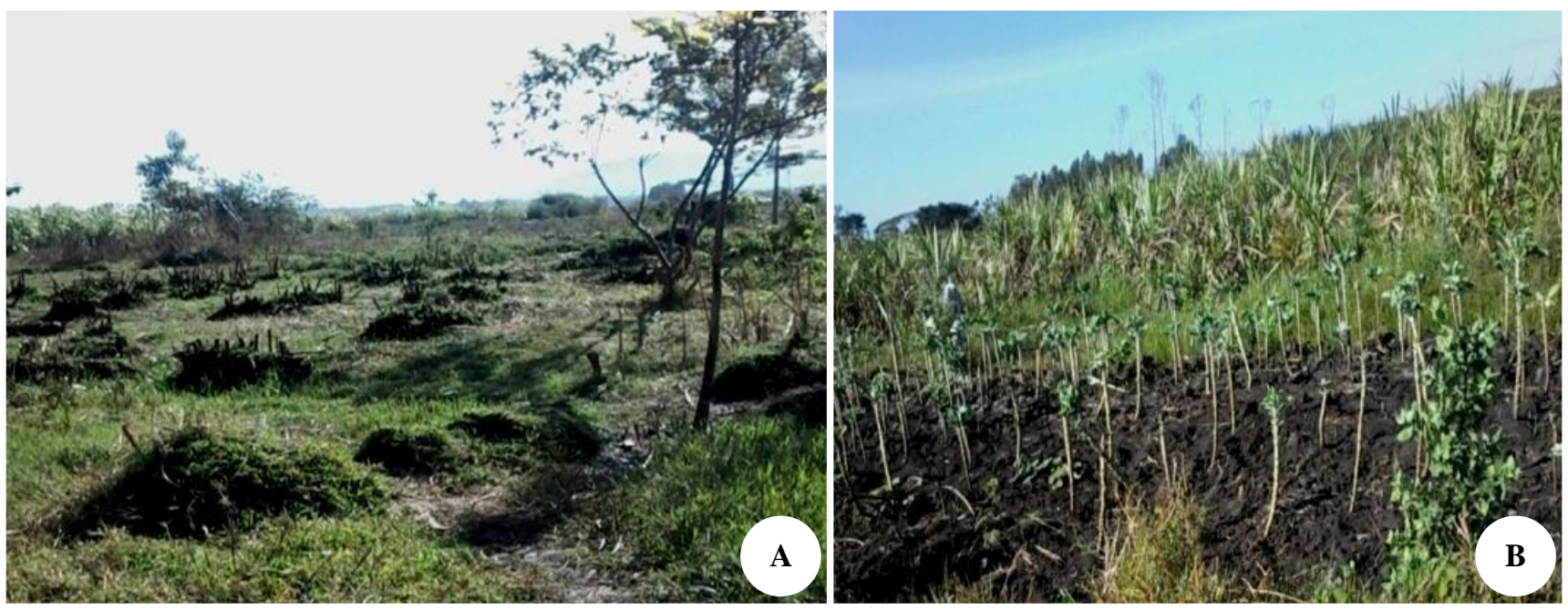

Figure 6. Cultivation along the edges of Sio Port Swamp, stumps of sugarcane (A), kales and sugarcane (B) of Sio Port Swamp, Western Kenya (Photo by SNW, Dec 2013)

The persistence of such plants could lead to alteration of the structure of papyrus swamps in the long run. The invasion was enhanced by siltation, where the vegetation was swept down the slope from the land to the lake.

Siltation was common in Sio's transect, where River Sio enters Lake Victoria from upstream. The watercolor in this part of the swamp was brown, indicating the presence of soil particles; compared to the color of the water in other parts of the swamp-agricultural activities in the upstream facilitated siltation. However, the water's brown color faded as the Sio transect opened into Lake Victoria. This part of the swamp where sedimentation was common also had the highest rate of sand harvesting activity.

\section{Birds' habitat quality}

The quality of the birds' habitat was described regarding the structural characteristics of height and density of vegetation. The height of papyrus culms was also defined regarding the young, immature, and mature growth stages. Examples of habitat disturbance such as clearing vegetation affected the habitat quality (height and density) directly, for instance, by reducing the vegetation cover. The other form of disturbance, that is, invasion by terrestrial and aquatic plants, affected the habitat quality indirectly through, for instance, changing its vertical and horizontal structure.

Vegetation height and density are essential characteristics for breeding birds, especially papyrus specialist birds. Therefore, disturbance effects on papyrus height and density could negatively affect endemic birds.

\section{Vegetation height in mixed and pure papyrus sites}

Pure papyrus sites had the highest mean (+SD) vegetation height in all the three height ranges compared to mixed papyrus sites, as shown in Table 4. No significant difference in vegetation with a height in the range of $0-2 \mathrm{~m}$ $(\mathrm{t}=-2.088, \mathrm{df}=18, \mathrm{p}=0.081)$ both in mixed and pure papyrus sites. However, there was a significant difference in vegetation with a height in the range of $2-4 \mathrm{~m}(\mathrm{t}=-5.966$, $\mathrm{df}=18, \mathrm{p}=0.000)$ and $4-6 \mathrm{~m}(\mathrm{t}=-2.424, \mathrm{df}=9, \mathrm{p}=0.038)$ in mixed and pure papyrus sites.

Pure papyrus sites recorded the highest mean height of vegetation in all ranges compared to the mixed papyrus sites. Pure papyrus sites were least disturbed; hence the top mean height for the plant was recorded in all height ranges.

Vegetation density in mixed and pure papyrus sites.

$\mathrm{V}$ papyrus sites had the highest mean $(+\mathrm{SD})$ vegetation density than pure papyrus sites (Table 5). Despite the difference in the mean frequencies of the plant in mixed and pure papyrus sites, t-test results showed that they were not significantly different $(\mathrm{t}=2.079, \mathrm{df}=18, \mathrm{p}=0.052)$.

Mixed papyrus sites had the highest mean $( \pm$ SD) density than the pure papyrus site in all height ranges (Table 6. There was a significant difference in the density of vegetation with a height in the range of $0-2 \mathrm{~m}(\mathrm{t}=2.495$, $\mathrm{df}=18, \mathrm{p}=0.023)$ in mixed and pure papyrus sites.

On the other hand, pure papyrus sites had the highest mean $( \pm$ SD) density of vegetation with a height in the range of 2-4 $\mathrm{m}$ and $4-6 \mathrm{~m}$. [Table 3.5]. There was no significant difference in the density of vegetation with a height in the range of $2-4 \mathrm{~m}(\mathrm{t}=-0.223, \mathrm{df}=18, \mathrm{p}=0.826)$ in mixed and pure papyrus sites. However, there was a significant difference in the density of vegetation with a height in the range of 4-6 m $(t=-2.387, d f=9, p=0.041)$ in the mixed and pure papyrus sites.

Mixed papyrus sites had the highest mean density of young papyrus vegetation ( $0-2 \mathrm{~m}$ high) than pure papyrus sites. Both strata had a small number of immature papyrus vegetation (2-4 $\mathrm{m}$ high). Tall mature papyrus vegetation (4$6 \mathrm{~m}$ high) was scanty in the two strata, though higher in pure papyrus sites than in mixed papyrus sites (Table 6). 
Table 4. Average (+SD) height of vegetation in three ranges in mixed and pure papyrus sites in Sio Port Swamp, Western Kenya

\begin{tabular}{lccc}
\hline & \multicolumn{3}{c}{ Height range } \\
\cline { 2 - 4 } Stratum & $\mathbf{0 - 2} \mathbf{~ m}(\mathbf{n})$ & $\mathbf{2 - 4} \mathbf{~ m}(\mathbf{n})$ & $\mathbf{4 - 6} \mathbf{~ m ~ ( n )}$ \\
\hline Mixed papyrus site & $1.246+0.439$ & $2.45+2.235$ & $4.356+0.167$ \\
& $(419)$ & $(86)$ & $(8)$ \\
Pure papyrus site & $1.327+0.411$ & $4.070+1.304$ & $4.457+0.238$ \\
& $(153)$ & $(61)$ & $(21)$ \\
\hline
\end{tabular}

Table 5. Average (+ SD) density of vegetation in mixed and pure papyrus sites in Sio Port Swamp, Western Kenya

\begin{tabular}{lc}
\hline Site (n) & Mean density $\left(\mathbf{s t e m s} / \mathbf{m}^{\mathbf{2}}\right)$ \\
\hline Mixed papyrus site (513) & $42.75+15.23$ \\
Pure papyrus site (235) & $29.38+8.86$ \\
\hline
\end{tabular}

Note: $\mathrm{n}=$ total number of vegetation culms

Table 6. Average $(+\mathrm{SD})$ density $\left(\mathrm{stems} / \mathrm{m}^{2}\right)$ of vegetation in three height ranges in mixed and pure papyrus sites height range in Sio Port Swamp, Western Kenya

\begin{tabular}{lccc}
\hline Stratum & $\mathbf{0 - 2} \mathbf{~ m}(\mathbf{n})$ & $\mathbf{2 - 4} \mathbf{~ m}(\mathbf{n})$ & $\mathbf{4 - 6} \mathbf{~ m}(\mathbf{n})$ \\
\hline Mixed papyrus sites & $34.92+16.64$ & $7.17+2.887$ & 0 \\
& $(419)$ & $(86)$ & $(8)$ \\
Pure papyrus sites & $19.13+5.276$ & $7.63+3.739$ & $2.63+2.387$ \\
& $(153)$ & $(61)$ & $(21)$ \\
\hline
\end{tabular}

\section{Relationship between vegetation height and vegetation density}

Vegetation height in the range of $0-2 \mathrm{~m}$ was positively but not significantly correlated $(\mathrm{r}=0.129, \mathrm{p}=0.589)$ with vegetation density. Vegetation height in the range of $2-4 \mathrm{~m}$ was negatively but not significantly correlated $(\mathrm{r}=-0.066$, $\mathrm{p}=0.787$ ) with vegetation density. Vegetation height in the range of 4-6 m was positively correlated $(r=0.896, p=$ 0.000 ) with vegetation density; the correlation was highly significant. Regression equation produced by the relationship was $\mathrm{y}=0.714 \mathrm{x}+0.605, \mathrm{t}=4.331, \mathrm{p}=0.000$ and the relationship was statistically significant. A change in the height of papyrus vegetation resulted in a corresponding change in the density of papyrus vegetation. However, the change was not significant for papyrus vegetation in the range of $0-2 \mathrm{~m}$ and 2-4 $\mathrm{m}$. But, the change was significant for papyrus vegetation in the range of 4-6 $\mathrm{m}$.

\section{Distribution of papyrus endemic birds in Sio Port \\ Swamp \\ The frequency of occurrence of birds along transects}

The distribution of papyrus endemic birds along transects varied in various swamp parts. The delivery could have resulted from different forms of disturbance influencing the nature of vegetation along each transect.
Sio

Papyrus endemic birds did not occupy all points along Sio transects. Greater-swamp Warbler did not appear in points VI and VII along transect Sio. Northern Brownthroated Weaver was the only papyrus endemic bird recorded in point VII (Figure 8. A).

Analysis of Variance test results revealed that the distribution of papyrus endemic birds in point IV $(\mathrm{F}(3,24)$ $=3.542, p=0.033)$ was significantly different. However, the distribution of the papyrus endemic birds in point I ( $F$ $(3,24)=2.237, \mathrm{p}=0.115)$, point II $(\mathrm{F}(3,24)=0.333, \mathrm{p}=$ $0.801)$, point $\mathrm{III}(\mathrm{F}(3,24)=1.382, \mathrm{p}=0.277)$, point $\mathrm{V}(\mathrm{F}(3$, $24)=0.333, \mathrm{p}=0.801)$, point $\mathrm{VI}(\mathrm{F}(3,24)=1.022, \mathrm{p}=$ $0.404)$ and point VII $(\mathrm{F}(3,24)=1.000, \mathrm{p}=0.413)$ was not significantly different along Sio transect.

Points II, III, V, and VI were primarily affected by clearing vegetation through burning and harvesting, which, in turn, reduced the vegetation cover hence the low number of some of the birds such as the Greater Swamp-warbler. The great invasion by terrestrial and aquatic plants was recorded in I, II, and III points. Still, it did not affect the distribution of the endemic birds along the Sio transect.

\section{Busijo a}

In transect Busijo a, all points were occupied by the papyrus endemic birds, albeit the distribution along the transect was uneven. For example, White-winged Swampwarbler and Northern Brown-throated Weaver distribution were high in point II of the transect but low in point $\mathrm{V}$ of the same transect. In the spot, I of the transect, Greater Swamp-warbler, and Papyrus Gonolek were highly distributed. The distribution of Greater swamp warbler was low in point III, while that of Papyrus Gonolek was low in spot V. Point II recorded the highest distribution. In contrast, point $\mathrm{V}$ recorded the smallest distribution of three of the five endemic birds (Figure 8. B).

Analysis of Variance test results showed that the distribution of papyrus endemic birds in point II $(\mathrm{F}(3,24)=$ $3.649, \mathrm{p}=0.030$ ) was significantly different along transect Busijo a. However, the distribution of papyrus endemic birds in point $\mathrm{I}(\mathrm{F}(3,24)=1.319, \mathrm{p}=0.296)$, point $\mathrm{III}(\mathrm{F}(3$, $24)=2.560, \mathrm{p}=0.084)$, point IV $(\mathrm{F}(3,24)=1.718, \mathrm{p}=$ $0.195)$ and point $\mathrm{V}(\mathrm{F}(3,24)=0.085, \mathrm{p}=0.968)$ along transect Busijo a was not significantly different.

All points along transect Busijo a were invaded by terrestrial and aquatic plants hence the unequal distribution of the papyrus endemic birds in the five positions along the transect. Point III was the only point affected by the clearing of vegetation, thus changing the distribution of papyrus endemic birds, which was dropped at this point for most of the birds (Figure 8. C).

\section{Busijo b}

Transect Busijo $b$ had a small number of five papyrus endemic birds. Northern Brown-throated Weaver was highly distributed in both points along the transect, followed by Papyrus Gonolek and Greater Swamp-warbler. White-winged Swamp-warbler was only distributed at one point along the transect (Figure 8.D). 
The distribution of papyrus endemic birds in point $\mathrm{I}(\mathrm{F}$ $(3,24)=1.827, \mathrm{p}=0.175)$ and point $\mathrm{II}(\mathrm{F}(3,24)=2.078, \mathrm{p}=$ 0.135), was not significantly different along transect Busijo a. Two forms of disturbance that altered Point II include vegetation clearing and invasion by terrestrial and aquatic plants, while point I was only affected by vegetation removal. However, the endemic birds were lowly distributed in the two points due to low vegetation cover and low density of tall papyrus vegetation.

\section{Daniel}

Papyrus endemic birds have distributed unevenly in all points along transects Daniel. Point V recorded the lowest distribution of Papyrus Gonolek, Northern Brown-throated Weaver, and Greater Swamp-warbler. White-winged Swamp-warbler was highly distributed in position II, Northern Brown-throated Weaver, Papyrus Gonolek, and Greater Swamp-warbler were highly distributed in position III (Figure 8. E).

ANOVA results showed that the distribution of papyrus endemic birds in point III $(\mathrm{F}(3,24)=3.093, \mathrm{p}=0.050)$ and point IV $(\mathrm{F}(3,24)=4.731, \mathrm{p}=0.012)$ along transect Daniel was significantly different. However, the distribution of papyrus endemic birds in point $\mathrm{I}(\mathrm{F}(3,24)=0.728, \mathrm{p}=$ $0.547)$, point II $(\mathrm{F}(3,24)=2.692, \mathrm{p}=0.074)$ and point $\mathrm{V}(\mathrm{F}$ $(3,24)=0.982, \mathrm{p}=0.421)$ along transect Daniel was not significantly different.

Points IV and V were affected by vegetation clearing and invasion by terrestrial and aquatic plants, hence the small number of papyrus endemic birds recorded in these points. Even though vegetation clearing was found in most of the points along the transect, papyrus endemic birds still existed in some of these points. Mature papyrus was the main stage of growth that was cut, leaving behind the young and immature papyrus that the endemic birds still inhabited.

\section{Ongaro}

Papyrus endemic birds are distributed unevenly along transect Ongaro, with some points lacking these birds. Greater Swamp-warbler, Papyrus Gonolek, and Whitewinged Swamp-warbler did not occur in some parts along the transect.

Greater Swamp-warbler did not occur in points II, III, IX, and X. White-winged Swamp-warbler did not happen in spots IX, X, and XI. Papyrus Gonolek did not happen in locations VIII, IX, and X. However, Northern Brownthroated Weaver occurred in all points along the transect (Figure 8. F).

Analysis of Variance test results demonstrated that the distribution of papyrus endemic birds in point $\mathrm{I}(\mathrm{F}(3,24)=$ $6.152, \mathrm{p}=0.004)$, point II $(\mathrm{F}(3,24)=3.667, \mathrm{p}=0.030)$, point $\mathrm{V}(\mathrm{F}(3,24)=3.273, \mathrm{p}=0.042)$, point IX $(\mathrm{F}(3,24)=$ $10.000, \mathrm{p}=0.000)$ and point $\mathrm{X}(\mathrm{F}(3,24)=7.353, \mathrm{p}=0.002)$ was significantly different along transect Ongaro. However, the distribution of papyrus endemic birds in point III $(\mathrm{F}(3,24)=1.425, \mathrm{p}=0.265)$, point $\mathrm{IV}(\mathrm{F}(3,24)=$ $0.510, \mathrm{p}=0.680)$, point VI $(\mathrm{F}(3,24)=2.222, \mathrm{p}=0.117)$, point VII $(\mathrm{F}(3,24)=1.528, \mathrm{p}=0.238)$ and point $\mathrm{XI}(\mathrm{F}(3$, $24)=1.286, \mathrm{p}=0.307$ ) was not significantly different along transect Ongaro.

Vegetation clearing was noted in points II, III, VI, IX, and $\mathrm{X}$. Tall mature papyrus was profoundly affected. Some papyrus endemic birds were not distributed in some of these points since they preferred tall, dense papyrus vegetation because they are very secretive.

\section{Distribution of birds across Sio Port Swamp}

Papyrus endemic birds were unevenly distributed across Sio Port Swamp, starting from transect Busijo a to the left to transect Sio to the right. The distribution of the majority of the papyrus endemic birds across Sio Port Swamp tends to increase. The distribution of all the endemic birds was lowest in transect Busijo $b$ and highest in transect Ongaro (Figure 8. G).

Papyrus endemic birds were lowly distributed across the swamp, where enormous disturbance effects. The influence of disturbance on vegetation height and density lowered the quality of the habitat to support papyrus endemic bird species.

Analysis of Variance tests showed that the distribution of papyrus endemic birds; White-winged Swamp-warbler $(\mathrm{F}(4,16)=0.331 \mathrm{p}=0.852)$, Papyrus Gonolek $(\mathrm{F}(4,16)=$ $1.182, \mathrm{p}=0.367)$, Northern Brown-throated Weaver $(\mathrm{F}$ (4, $16)=0.826, p=0.533)$ and Greater Swamp-warbler $(\mathrm{F}(4$, $16)=1.907, p=0.174$ ) was not significantly different across the swamp in all the five transects.

\section{The abundance of papyrus endemic birds along the disturbance gradient in Sio Port Swamp}

From the total 501 individuals of the target bird species, $44 \%$ were recorded in mixed papyrus sites, while 56\% were found in pure papyrus sites. The abundance of individual species in the two habitats did not vary significantly (Table 7). However, the Northern Brownthroated Weaver, White-winged Swamp-warbler, and Papyrus Gonolek predominantly occurred in pure papyrus stands.

Table 7. The abundance of papyrus endemic birds in mixed and pure papyrus sites in Sio Port Swamp Oct 2013-Mar 2014

\begin{tabular}{lcccc}
\hline \multicolumn{1}{c}{ Papyrus } \\
endemic bird & $\begin{array}{c}\text { Number in } \\
\text { mixed } \\
\text { papyrus } \\
\text { sites }\end{array}$ & $\begin{array}{c}\text { Abund. } \\
(\%)\end{array}$ & $\begin{array}{c}\text { Number } \\
\text { in pure } \\
\text { papyrus } \\
\text { sites }\end{array}$ & $\begin{array}{c}\text { Abund. } \\
(\%)\end{array}$ \\
\hline $\begin{array}{l}\text { Northern Brown- } \\
\text { throated weaver }\end{array}$ & 95 & 39.09 & 127 & 41.78 \\
$\begin{array}{l}\text { White-winged } \\
\begin{array}{l}\text { Swamp-warbler } \\
\text { Papyrus Gonolek }\end{array}\end{array}$ & 49 & 20.16 & 65 & 21.38 \\
$\begin{array}{l}\text { Greater Swamp- } \\
\text { warbler }\end{array}$ & 31 & 18.52 & 56 & 18.42 \\
\hline
\end{tabular}



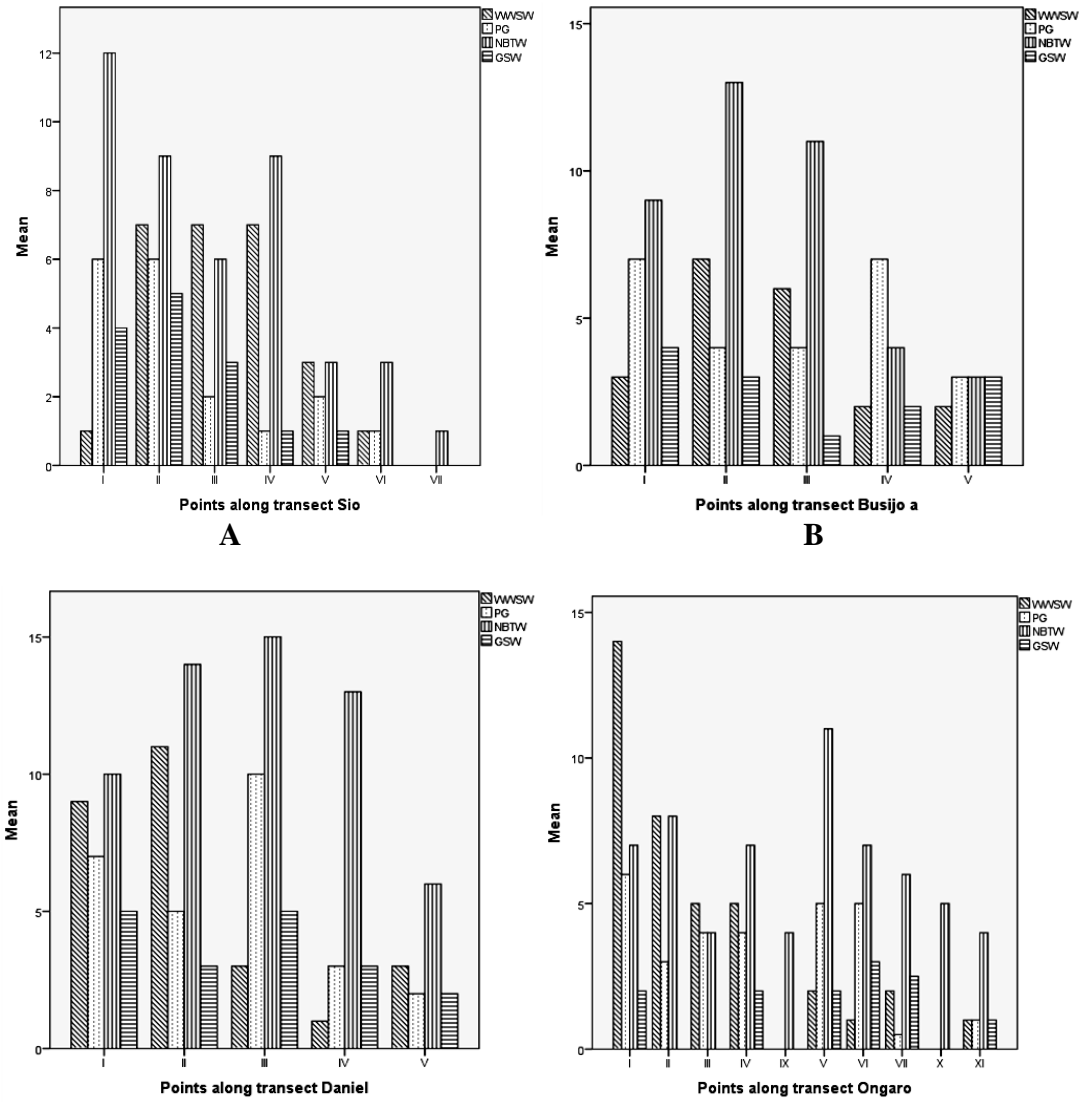

D

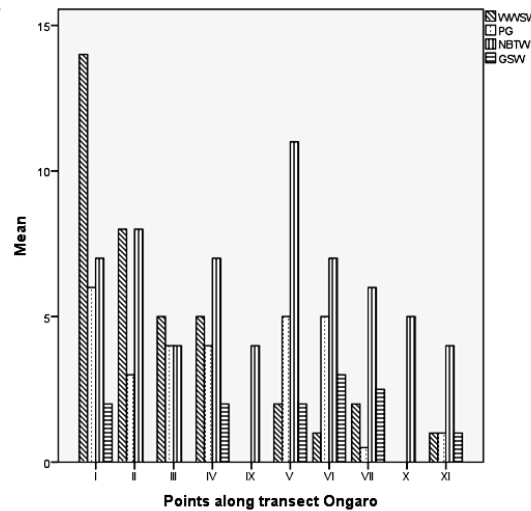

$\mathbf{E}$
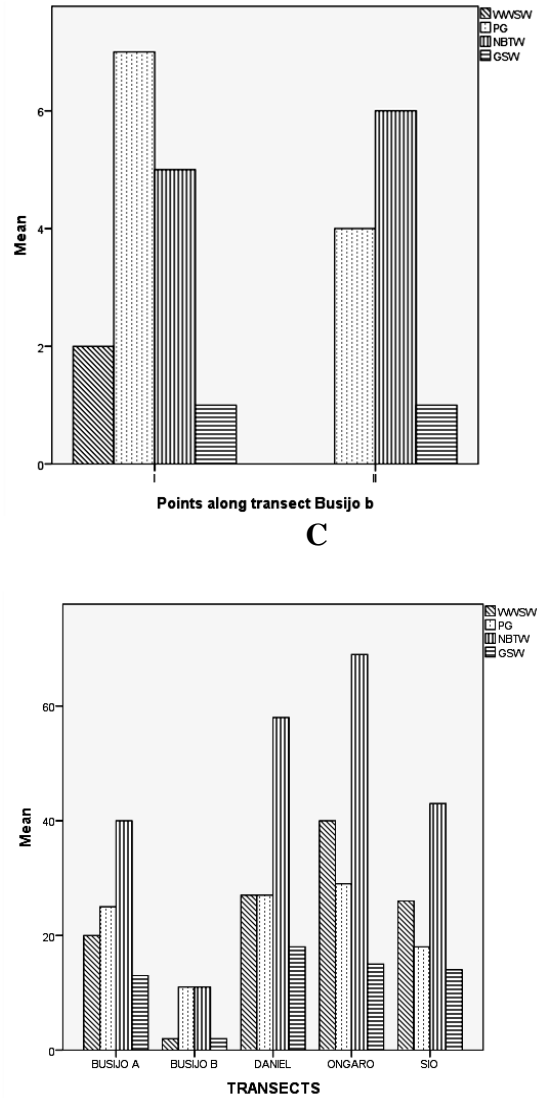

$\mathbf{F}$

Figure 8. Distribution of papyrus endemic birds along a transect in Sio Port Swamp, Western Kenya. A. Sio (October 2013 to November 2014). B. Busijo a, (October 2013 to March 2014). C. Busijo b, (October 2013 to March 2014). C. Daniel (October 2013 to March 2014). D. Ongaro (October 2013 to March 2014). E. All five transects of Sio Port Swamp. Note: WWSW-White-winge Swamp Warbler, GSW-Greater Swamp Warbler, NBTW-Northern Brown-throated Weaver, PG-Papyrus Gonolek

Analysis of Variance tests showed that the abundance of three out of the four endemic birds White-winged Swamp-warbler $(\mathrm{F}(1,28)=7.376, \mathrm{p}=0.011)$, Papyrus Gonolek $(\mathrm{F}(1,28)=5.331, \mathrm{p}=0.029)$, and Northern Brown-throated Weaver $(\mathrm{F}(1,28)=5.734, \mathrm{p}=0.024)$ was significantly different in mixed and pure papyrus sites. However, the abundance of Greater Swamp-warbler (F (1, 28) $=2.718, p=0.110$ ) was not significantly different in mixed and pure papyrus sites.

Papyrus endemic birds preferred sites with pure papyrus over sites with mixed papyrus. Pure papyrus sites had some tall, dense papyrus culms, thus creating a suitable environment for their survival. The tall and dense papyruses were necessary for their breeding and nesting.

\section{The relationship between the abundance of papyrus endemic birds and vegetation density}

The plenty of papyrus endemic birds was positively but not significantly correlated $(\mathrm{r}=0.031, \mathrm{p}=0.898)$ with vegetation density in the sampled locations. Therefore, an increase in vegetation density could cause an overall increasing trend in the abundance of papyrus endemic birds.
The abundance of papyrus endemic birds was negatively correlated with density of vegetation in the height range of $0-2 \mathrm{~m}(\mathrm{r}=-0.018, \mathrm{p}=0.941)$ and $2-4 \mathrm{~m}(\mathrm{r}$ $=-0.054, p=0.822$ ), albeit not significant. An increase in the vegetation density in the height range of $0-2 \mathrm{~m}$ and 2-4 $\mathrm{m}$ would reduce the abundance of papyrus endemic birds. Thus, the high vegetation density associated with young papyrus and grass was unfavorable to papyrus endemics.

The abundance of papyrus endemic birds was positively correlated with the vegetation density in the height range of $4-6 \mathrm{~m}(\mathrm{r}=0.465, \mathrm{p}=0.039)$. A change in vegetation density (height range of 4-6 m) could change the abundance of papyrus endemic birds. Regression analysis between stem culm density and number of birds produced a statically significant relationship $\mathrm{y}=2.590 \mathrm{x}+0.465, \mathrm{t}=$ $2.227, \mathrm{p}=0.039$. Change in culm density explained the 44 $\%$ variation in bird abundance.

\section{Discussion}

Factors influencing the population of papyrus endemic birds

Papyrus swamps are buffers between terrestrial and aquatic ecosystems, acting as silt traps and nutrient filters conserving water quality (Gaudet 1980). Tall stems with or 
without inflorescence characterize natural papyrus wetlands. They also consist of areas of green water, dense reeds of young, mature, and immature reeds interspersed with grass and other semi-aquatic herbaceous vegetation. There are also some parts with dead papyrus culms and inflorescence. The dominant vegetation in Sio Port Swamp was papyrus Cyperus papyrus with tall culms of about 5.5 $\mathrm{m}$. Papyrus vegetation was densely distributed in some parts of the swamps, but in other regions were patchily distributed. As many as $76.47 \%$ of papyrus vegetation were young and regenerated (0-2 m high), $19.65 \%$ were immature $(2-4 \mathrm{~m})$, whereas $3.88 \%$ were tall mature papyruses (4-6 m high).

This study suggests that the population of papyrus endemic birds was influenced by the distribution of papyrus, composition of papyrus, culm height, culm density, and presence of forms of disturbance. Papyrus endemic birds were abundant in sites with a high distribution of papyrus. Pure papyrus sites, which had papyrus as the primary vegetation species, had the highest number of papyrus endemic birds than disturbed sites. Mixed papyrus sites had a mixture of vegetation, especially papyrus and grass species, such as Vossia cuspidata. Papyrus endemic birds had the lowest number along with the edges of the swamp. Papyrus birds respond to changes in papyrus conditions by distributing themselves in more natural papyrus stands (Owino and Ryan 2006). The population of papyrus endemic birds was influenced by the composition of papyrus vegetation that is young, immature, and mature. Pure papyrus sites are generally composed of immature and mature papyrus. Such sites are inhabited by the high population size of the papyrus endemic birds. Papyrus specialist birds exist in large numbers in tall, dense, and least disturbed papyrus stands (Owino and Ryan 2006).

This study also described that papyrus culm height influences the population of papyrus endemic birds. Pure papyrus sites had the highest average vegetation height in all height ranges compared to mixed papyrus sites. Papyrus endemic birds existed in large numbers in pure papyrus sites compared to various places. Papyrus culm density also influenced the population size of papyrus endemic birds. Pure papyrus locations had a high vegetation density in the height range of 2-4 $\mathrm{m}$ and 4-6 $\mathrm{m}$. Mixed papyrus sites, on the contrary, had a high density of vegetation in the height range of 1-2 m. Papyrus endemic birds are significantly associated with the vegetation density in locations, especially with tall papyrus vegetation in the 4-6 $\mathrm{m}$. These results indicate that the endemic birds favored dense pure papyrus vegetation over very dense mixed vegetation.

This study also showed that the presence of various forms of disturbance influenced the population density of papyrus endemic birds. Anthropogenic disturbances on habitats affected the habitat structural characteristics, especially vegetation height and density. These essential characteristics influence the distribution and abundance of papyrus endemic birds in general (Owino and Ryan 2007).

Forms of habitat disturbance, such as papyrus clearing, affected the habitat quality directly by reducing vegetation cover and height. Papyrus is usually cut to provide material to thatch roofs, build fences, and make handicrafts such as mats and trays (Maclean et al., 2003). Other forms of disturbance, such as invasion by terrestrial and aquatic plants, indirectly affected the habitat quality by altering the vertical structure. The abundance of papyrus endemic birds in mixed papyrus sites was lower than that of pure papyrus stands. The type and nature of each disturbance affected the life of the habitat, mainly vegetation cover, which affected the abundance of papyrus endemic birds. In tropical areas, species that benefit from upheaval are often widespread generalists. Generally, disturbance does not favor specialist species confined to one habitat type (Thiollay 1992; Hammer et al. 1997; Hammer and Hill 2000; Barlow et al. 2002).

\section{Factors influencing habitat distribution and structure}

From the survey conducted in Sio Port Swamp, habitat distribution was affected by the accessibility of the swamp by the locals. Areas easily accessed by the locals showed a mixture of vegetation species compared to those with minimal visits. An example of this situation is that parts of the swamp closer to the edges where the locals gathered to sell and buy fish had more of Vossia cuspidata than Cyperus papyrus.

Besides, accessibility encouraged activities such as livestock grazing and cultivation along the edges of the swamp, which in some areas, extended deep into the swamp. This may have contributed extensively to the presence of invasive terrestrial and aquatic plants and reduction in papyrus cover since locals use it for fuel, matmaking, and thatching of roofs (Abila 1998; Otieno et al. 1998). According to the results of this study, the structure of the habitat is influenced by the forms of disturbance present and their effect on the habitat. Clearing vegetation significantly contributed to the decrease in vegetation cover and domination of juvenile papyrus vegetation in the height range of $0-2 \mathrm{~m}$ and $2-4 \mathrm{~m}$.

Our study also proved that the height and stage of growth of vegetation species present in a habitat disturbed the structure of the habitat. For instance, mixed papyrus sites had a higher average vegetation density value than pure papyrus sites. Most vegetation was in the range of 0-2 $\mathrm{m}$. They had a smaller girth and short height than mature papyrus culms of 2-4 $\mathrm{m}$ and 4-6 $\mathrm{m}$ high, accordingly a high number per square meter. Some negative correlation was found between the number of adults and senescing culms and papyrus culm height. However, young culms are positively correlated with culm density (Maclean et al. 2006)

\section{Impacts of human disturbance on habitats and birds}

Implications for habitats. This study shows that forms of human interference such as vegetation clearing lower vegetation cover in habitats, therefore lowering their quality to support biodiversity. Papyrus habitat loss represents a potential threat to the conservation of biodiversity (Muthuri et al. 1989; Boar et al. 1999; Fishpool and Evans 2001). It was noted that the local people washed clothes along the edges of Sio Port Swamp and at the landward end of some transects. Livestock 
grazing, cultivation, regular visits, and human activities along edges of the swamp led to the trampling of vegetation in such regions. Consequently, it could result in a reduction in the size of the habitat in the long run. The cuts in habitat areas have direct implications on their quality to support species (Andren 1994; Fahrig and Merriam 1994; Noss and Csuti 1997; Bender et al. 1998; Esikuri 1998; Benoit and Askins 2002; Davis 2004).

Impacts on birds. This study showed that human disturbance affects bird distribution and abundance. Various forms of disturbance play a key role in determining the kind of species and their respective numbers to utilize the affected sites. In general, papyrus endemic birds were most abundant in pure papyrus sites. This study demonstrated that Northern Brown-throated Weaver exists in large numbers in almost all sites, both disturbed and undisturbed. These results, therefore, indicate that papyrus specialist birds may survive to some extent in a habitat with various forms of disturbance. Still, the degree of interference will determine the abundance of these birds. Continued degradation of papyrus swamps may affect the ecological requirements of papyrus endemic birds while creating habitats for generalists and even predator species in and around the wetlands. Reduced nesting sites, for instance, may cut the breeding success of these species (Owino and Ryan 2006).

In conclusion, as many as $44 \%$ of the papyrus endemic birds utilized mixed papyrus sites while $56 \%$ employed pure papyrus sites. Therefore, pure papyrus sites were the most utilized of the two habitats. The habitat structure in Sio Port Swamp was mainly composed of papyrus Cyperus papyrus. However, other vegetation types such as Hippo grass, Vossia cuspidate, and Water hyacinth Eichhornia crassipes were also present. Papyrus vegetation was densely distributed deep within the swamp compared to the edges of the swamp. The primary forms of disturbance observed in Sio Port Swamp were papyrus clearing and invasion by terrestrial and aquatic plants. Papyrus endemic birds preferred sites with tall, dense, and minimum disturbed papyrus culms. Even though they seemed to be around in the concerned regions, their abundance in such areas was low and limited to the level of disturbance. Habitat disturbance alters the population size of the biodiversity supported by the given habitat. When the population size is modified, the animals or plants are distributed selectively in the different parts of the habitat, depending on habitat degradation. Their abundance is low in profoundly disturbing sites and high in the least disturbed sites. Advance management of papyrus clearing is required for the long-term conservation of biodiversity. Since papyrus vegetation is known to regenerate rapidly and has high productivity following disturbance (Muthuri et al. 1989; Boar et al. 1999), the conservation of papyrus can still be compatible with human use if papyrus clearance is regulated.

\section{REFFERENCE}

Abila R. 1998. Utilisation and economic valuation of the Yala swamp wetland. Proceedings of the $21^{\text {st }}$ International Conference on Wetlands and Development. Dakar, November 1998.

Andren H. 1994. Effects of habitat fragmentation on birds and mammals in landscapes with different proportions of suitable habitat: a review. Oikos 71: 355-366. DOI: 10.2307/3545823.

Balirwa JS. 1998. Lake Victoria Wetlands and The Ecology of The Nile Tilapia, Oreochromis niloticus Linne. [Dissertation]. Wageningen Agricultural University, Wageningen, Netherlands.

Barasa B, Majaliwa JGM, Lwasa S, Obando J. 2011. Magnitude and transition potential of land-use/cover changes in the transboundary River Sio catchment using remote sensing and GIS. Ann GIS 17 (1): 73-80. DOI: 10.1080/19475683.2011.558023/

Barlow J, Haugaasen T, Peres CA. 2002. Effects of ground fires on understorey bird assemblages in Amazonian forests. Biol Conserv 105 (2): 157-169. DOI: 10.1016/S0006-3207(01)00177-X.

Bender DJ, Contreras TA, Fahrig L. 1998. Habitat loss and population decline: a meta analysis of the patch size effect. Ecology 79 (2): $517-$ 533. DOI: 10.1890/0012-9658(1998)079[0517:HLAPDA]2.0.CO;2.

Bennun LA, Howell K. 2000. Birds in African Forest Biodiversity. Earthwatch Institute Europe, UK.

Bennun LA, Njoroge P. 1999. Important Bird Areas in Kenya, Nature Kenya, Nairobi. DOI: 10.5962/bhl.title.87589.

Benoit LK, Askins RA. 2002. Relationship between habitat area and distribution of tidal marsh birds. Wilson Bull 114 (3): 314-324. DOI: 10.1676/0043-5643(2002)114[0314:RBHAAT]2.0.CO;2.

BirdLife International. 2004. Threatened Birds of The World. Bird Life International, Cambridge, UK.

Boar RR, Harper D M, Adams CS. 1999. Biomass allocation in Cyperus papyrus in a tropical wetland, Lake Naivasha, Kenya. Biotropica 31 (3): 411-421. DOI: 10.1111/j.1744-7429.1999.tb00383.x.

Britton PL. 1978. Seasonality, density, and diversity of birds of a papyrus swamp in Western Kenya. Ibis 120 (4): 450-466. DOI: 10.1111/j.1474-919X.1978.tb06811.x.

Burnham KP, Anderson DR, Laake JL. 1980. Estimation of density from line transects sampling of biological populations. Wildlife Monogr 72: 3-202.

Byaruhanga A, Kasoma P, Pomeroy D. 2001. Important Bird Areas in Uganda. The East Africa Natural History Society, Kampala, Uganda.

Davis SK. 2004. Area sensitivity in grassland passerines: Effects of patch size, patch shape and vegetation structure on birds abundance and occurrence in southern Saskatchewan. Auk 121 (4): 1130-1145. DOI: 10.1642/0004-8038(2004)121[1130:ASIGPE]2.0.CO;2.

Ellery WN, Ellery K, Rogers KH, McCarthy TS. 1995. The role of Cyperus papyrus $\mathrm{L}$. in channel blockage and abandonment in the north-eastern Okavango Delta, Botswana. Afr J Ecol 33 (1): 25-49. DOI: $10.1111 /$ j.1365-2028.1995.tb00779.x.

Esikuri EE. 1998. Spatio-Temporal Effects of Land Use Changes in A Savanna Wildlife Area of Kenya. [Dissertation]. Virginia Polytechnic Institute and State University, Blacksburg, VA.

Fahrig L, Merriam G. 1994. Conservation of fragmented populations. Conserv Biol 8 (1): 50-59. DOI: 10.1046/j.15231739.1994.08010050.x.

Fishpool LDC, Evans MI. 2001. Important Bird Areas in Africa and Associated Islands: Priority Sites for Conservation. Bird Life International, Cambridge, UK.

Gaudet J. 1980. Papyrus and the ecology of Lake Naivasha. Nat Geogr Soc Res Rep 12: 267-272.

GoK. 2009. Flood Mitigation Strategy, Ministry of Environment, Water and Natural Resources. Nairobi, Kenya.

Hammer KC, Hill JK, Lace LA, Langan AM. 1997. Ecological and biogeographical effects of forest disturbance on tropical butterflies of Sumba, Indonesia. J Biogeogr 24 (1): 67-75. DOI: 10.1111/j.13652699.1997.tb00051.x.

Hammer KC, Hill JK. 2000. Scale-dependent effects of habitat disturbance on species richness in tropical forests. Conserv Biol 14 (5): 1435-1440. DOI: 10.1046/j.1523-1739.2000.99417.x.

Hughes RH, Hughes JS. 1992. A Directory of African Wetlands. World Conservation Union, Gland/United Nations Environment Programme (UNEP), Nairobi/World Conservation Monitoring Centre (WCMC), Cambridge, UK. 
Kairu JK. 2001. Wetland use and impact on Lake Victoria, Kenya region. Lakes Reservoirs Res Manag 6 (2): 117-125. DOI: 10.1046/j.14401770.2001.00135.x.

Kamau P. 2004. Forage Diversity and Impact of Grazing Management on Rangeland Ecosystems in Mbeere district, Kenya. LUCID Working Paper Series No. 36.

Kenya Wetland Atlas. 2012. Ministry of Environment and Natural Resources, Kenya. Kenya Wetland Forum. Why conserve wetlands?

Lathrop RG. 2011. The highlands: Critical resources, treasured landscape. Rivergate Books, New Brunswick, N.J.

Maclean IMD, Hassall M, Boar RR, Lain RL. 2006. Effects of disturbance and habitat loss on papyrus-dwelling passerines. Biol Conserv 131 (3): 349-358. DOI: 10.1016/j.biocon.2005.12.003.

Maclean IMD, Hassall M, Boar RR, Nasirwa O. 2003. Effects of habitat degradation on avian guilds in East African papyrus Cyperus papyru swamps. Bird Conserv Intl 13 (4): 283-297. DOI: 10.1017/S0959270903003216.

Mafabi P. 2000. The role of wetland policies in the conservation of water birds: The case of Uganda. Ostrich 71 (1-2): 96-98. DOI 10.1080/00306525.2000.9639880.

Muthuri FM, Jones MB, Imbamba SK. 1989. Primary productivity of papyrus (Cyperus papyrus) in a tropical swamp; Lake Naivasha, Kenya. Biomass 18 (1): 1-14. DOI: 10.1016/0144-4565(89)90077-2.

Muthuri FM, Kinyamario DI. 1989. The nutritive value of papyrus Cyperus papyrus. Econ Bot 43 (1): 23-30. DOI 10.1007/BF02859321.

Mwakubo SM, Ikiara MM. 2006. Determinants of Papyrus Harvesting in the Yala swamp, Kenya, Egerton University Kenya, Kenya.

Nasirwa O, Njoroge P. 1997. Papyrus-endemic birds in the fringing swamps of Lake Victoria, western Kenya. Ornithology 28: 1-10.
Noss RF, Csuti B. 1997. Habitat Fragmentation. Principles of Conservation Biology, Sinauer, Sunderland, MA.

Odino M. 2011. Papyrus Yellow Warbler (Chloropeta glacilirostris) Survey in Sio Port Swamp Important Bird Area, KE IBA 60, National Museums of Kenya.

Otieno M, Imende S, Haya G, Kibos S, Ouma Z. 1998. Sustainable management and utilization of wetlands and wetlands products, pilot project: Market survey of wetland products in Busia, Siaya, Kisumu, and Kisii Districts report. Lake Victoria Environmental management project.

Owino OA, Ryan GP. 2007. Recent papyrus swamp habitat loss and conservation implications in western Kenya. Wetlands Ecol Manag 15 (1): 1-12. DOI: 10.1007/s11273-006-9001-y.

Owino OA. 2006. Habitat associations of papyrus specialist birds at three papyrus swamps in western Kenya. African J Ecol 44 (4): 438-443. DOI: $10.1111 / \mathrm{j} .1365-2028.2006 .00652 . x$.

Ramsar Convention Secretariat. 2006. The Ramsar Convention Manual: A Guide to the Convention on Wetlands (Ramsar, Iran, 1971), $4^{\text {th }}$ ed. Ramsar Convention Secretariat, Gland Switzerland.

Sutherland WJ. 1996. Ecological Census Techniques a Handbook. University of East Anglia, Cambridge University Press, UK.

Sutton SL, Hudson PJ. 1981. Arthropod succession and diversity in umbels of Cyperus papyrus L. Biotropica 13: 117-120. DOI: $10.2307 / 2387713$.

Thiollay JM. 1992. Influence of selective logging on bird species-diversity in Guianan rain forest. Conserv Biol 6 (1): 47-63. DOI: 10.1046/j.1523-1739.1992.610047.x.

Vande Weghe JP. 1981. Avifauna of papyrus in Rwanda and Burundi. Gerfaut 71: 489-536.

Zar JH. 2010. Biostatistical Analysis. Prentice Hall, New Jersey. 